\title{
Calcifications afloat: bad omens in maxillary sinus augmentation
}

\author{
Daniele Di Pasquale, Alberto Maria Saibene, Valentina Bebi, Giovanni Felisati
}

Department of Otolaryngology, San Paolo Hospital, University of Milan, Milan, Italy

\section{Correspondence to} Profeessor Giovanni Felisati, giovanni.felisati@gmail.com

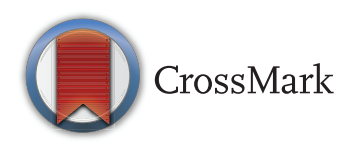

To cite: Di Pasquale $D$, Saibene AM, Bebi V, et al. BMJ Case Rep Published online: [please include Day Month Year] doi:10.1136/ bcr-2013-201581

\section{DESCRIPTION}

A 60-year-old patient was referred to our ear nose and throat (ENT) clinic for facial pain, bilateral midface swelling and purulent nasal discharge. The patient had undergone a bilateral maxillary sinus augmentation procedure 3 weeks before. A nasal endoscopy showed purulent material from both the middle meati, while oral examination revealed a left oroantral fistula.

The head CT scan (figure 1) showed both maxillary sinuses occupied by flogistic material with disperse calcifications and confirmed the left oroantral fistula. These calcifications hint towards a diagnosis of odontogenic sinusitis: multiple calcifications in a completely opacified maxillary sinus most likely represent infected grafts dislodged from the maxillary floor. In some cases, the fragments even tend to align to the mucociliary clearance flow. ${ }^{1}$

Maxillary augmentation is considered a safe and predictable answer to vertical maxillary bone atrophies. Grafting the particulate bone and covering the lateral window access with a collagen membrane has been shown to increase implant survival. ${ }^{2}$ The use of piezoelectric tools has gained popularity to reduce damage to the Schneiderian membrane.

According to the classification of sinonasal complications following dental treatment, the patient showed a class 1a complication (condition following maxillary sinus augmentation). ${ }^{3}$ The patient was consequentially treated with an association of functional endoscopic

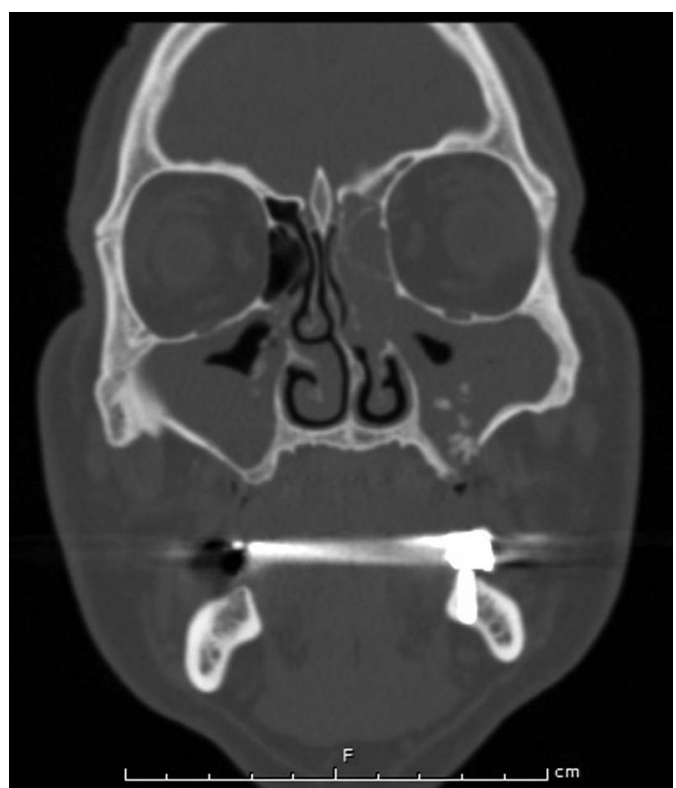

Figure 1 Coronal head CT scan. The image showing both the maxillary sinuses occupied by flogistic material with bilateral disperse calcifications. A left oroantral fistula can also be easily recognised. sinus surgery and an intraoral approach as suggested by Chiapasco et al. ${ }^{4}$ A bilateral antrostomy restored the maxillary drainage and allowed the removal of bony fragments resulting from the prior sinus augmentation. The intraoral approach on the other hand was required to completely remove the grafting material and close the oroantral fistula with local rotation flaps. The patient was intravenously administered levofloxacin $750 \mathrm{mg}$ for 2 days followed by oral levoxacin $500 \mathrm{mg}$ for 7 days. Endoscopic follow-up at 1, 2, 4 and 12 weeks confirmed complete healing of the sinonasal complex.

\section{Learning points}

- Grafting the particulate bone and covering the lateral window access with a collagen membrane has been shown to increase implant survival. The use of piezoelectric tools has gained popularity to reduce damage to the Schneiderian membrane.

- Before performing a maxillary sinus floor augmentation always evaluate the sinonasal status of the patient and patency of the ostiomeatal complex: this will allow you to maximise the success rate of the grafting.

- Maxillary sinus floor augmentation complications cannot be treated by nasal endoscopy alone: a combined oral access is not only advisable but is also required along with adequate antibiotic therapy.

Contributors DDP and AMS retrieved the data and were involved in writing the article. VB and GF performed the surgical procedure on the patient. GF acted as supervisor and senior ENT consultant.

Competing interests None.

Patient consent Obtained.

Provenance and peer review Not commissioned; externally pee reviewed.

\section{REFERENCES}

1 Felisati $G$, Saibene AM, Lenzi $R$, et al. Late recovery from foreign body sinusitis after maxillary sinus floor augmentation. BMJ Case Rep. Published Online First: 23 Dec 2012. doi:10.1136/ bcr-2012-007434

2 Wallace SS, Froum SJ. Effect of maxillary sinus augmentation on the survival of endosseous dental implants. A systematic review. Ann Periodontol 2003;8:328-43.

3 Felisati G, Chiapasco M, Lozza P, et al. Sinonasal complications resulting from dental treatment: outcome-oriented proposal of classification and surgical protocol. Am J Rhinol Allergy 2013;27:101-6.

4 Chiapasco M, Felisati G, Zaniboni M, et al. The treatment of sinusitis following maxillary sinus grafting with the association of functional endoscopic sinus surgery (FESS) and an intra-oral approach. Clin Oral Imp/ Res 2013:24:623-9. 
Copyright 2013 BMJ Publishing Group. All rights reserved. For permission to reuse any of this content visit http://group.bmj.com/group/rights-licensing/permissions.

BMJ Case Report Fellows may re-use this article for personal use and teaching without any further permission.

Become a Fellow of BMJ Case Reports today and you can:

- Submit as many cases as you like

- Enjoy fast sympathetic peer review and rapid publication of accepted articles

- Access all the published articles

- Re-use any of the published material for personal use and teaching without further permission

For information on Institutional Fellowships contact consortiasales@bmjgroup.com

Visit casereports.bmj.com for more articles like this and to become a Fellow 